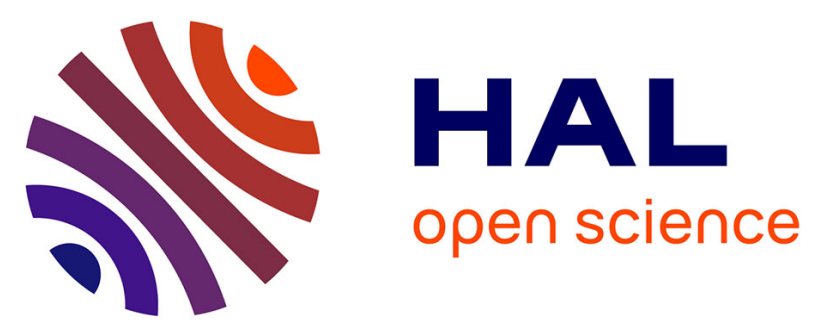

\title{
Lack of in vitro constitutive activity for four previously reported TSH receptor mutations identified in patients with nonautoimmune hyperthyroidism and hot thyroid carcinomas
}

\author{
Ralf Paschke, Holger Jaeschke, Sandra Mueller, Markus Eszlinger
}

\section{To cite this version:}

Ralf Paschke, Holger Jaeschke, Sandra Mueller, Markus Eszlinger. Lack of in vitro constitutive activity for four previously reported TSH receptor mutations identified in patients with nonautoimmune hyperthyroidism and hot thyroid carcinomas. Clinical Endocrinology, 2010, 73 (6), pp.815. 10.1111/j.1365-2265.2010.03872.x . hal-00593441

\section{HAL Id: hal-00593441 \\ https://hal.science/hal-00593441}

Submitted on 16 May 2011

HAL is a multi-disciplinary open access archive for the deposit and dissemination of scientific research documents, whether they are published or not. The documents may come from teaching and research institutions in France or abroad, or from public or private research centers.
L'archive ouverte pluridisciplinaire HAL, est destinée au dépôt et à la diffusion de documents scientifiques de niveau recherche, publiés ou non, émanant des établissements d'enseignement et de recherche français ou étrangers, des laboratoires publics ou privés. 


\section{CLINICAL ENDOCRINOLOGY}

\section{Lack of in vitro constitutive activity for four previously reported $\mathrm{TSH}$ receptor mutations identified in patients with nonautoimmune hyperthyroidism and hot thyroid carcinomas}

\begin{tabular}{|r|l|}
\hline Journal: & Clinical Endocrinology \\
\hline Manuscript ID: & CEN-2010-000358.R1 \\
\hline Manuscript Type/Office: & 2 Original Article - Europe, excluding UK \\
\hline Date Submitted by the \\
Author: & 22-Jul-2010 \\
\hline Complete List of Authors: & $\begin{array}{l}\text { Paschke, Ralf; University of Leipzig, Department for Internal } \\
\text { Medicine, Endocrinology and Nephrology } \\
\text { Jaeschke, Holger; University of Leipzig, Department for Internal } \\
\text { Medicine, Endocrinology and Nephrology } \\
\text { Mueller, Sandra; University of Leipzig, Department for Internal } \\
\text { Medicine, Endocrinology and Nephrology } \\
\text { Eszlinger, Markus; University of Leipzig, Department for Internal } \\
\text { Medicine, Endocrinology and Nephrology }\end{array}$ \\
\hline Key Words: & $\begin{array}{l}\text { Hyperthyroidism < Conditions: < Thyroid, Thyroid cancer < } \\
\text { Conditions: < Thyroid, TSH receptor }\end{array}$ \\
\hline
\end{tabular}

\section{SCHOLARONE $^{m}$ Manuscripts}


Lack of in vitro constitutive activity for four previously reported TSH receptor mutations identified in patients with nonautoimmune hyperthyroidism and hot thyroid carcinomas

Holger Jaeschke, Sandra Mueller, Markus Eszlinger, Ralf Paschke Department for Internal Medicine, Endocrinology and Nephrology, University of Leipzig, Germany

The authors have nothing to declare

\author{
Abbreviated title: TSHR mutations in thyroid disease \\ Key terms: nonautoimmune hyperthyroidism, TSHR, constitutively activating mutations \\ Word count: 2559 \\ Corresponding author: $\quad$ Prof. Dr. med. R. Paschke \\ Department for Internal Medicine, Endocrinology and \\ Nephrology, University of Leipzig \\ Liebigstrasse 20 \\ D- 04103 Leipzig, Germany \\ phone: + 49-341-97-13201, fax: + 49-341-97-13209 \\ e-mail: Ralf.Paschke@medizin.uni-leipzig.de
}




\begin{abstract}
Objective: Constitutively activating mutations of the TSHR are the major cause for nonautoimmune hyperthyroidism. Re-examination of constitutive activity previously determined in $\mathrm{CHO}$ cell lines recently demonstrated the caveats for the in vitro determination of constitutive TSHR activity, which leads to false positive conclusions regarding the molecular origin of hyperthyroidism or hot thyroid carcinomas.

Design: Mutations L677V and T620I identified in hot thyroid carcinomas were previously characterized in $\mathrm{CHO}$ and in 3T3-Vill cell lines, respectively, stably expressing the mutant without determination of TSHR expression. F666L identified in a patient with hot thyroid nodules, I691F in a family with nonautoimmune hyperthyroidism and F631I identified in a hot thyroid carcinoma were not characterized for their in vitro function. Therefore, we decided to (re)evaluate the in vitro function of these five TSHR variants by determination of the cell surface expression, intracellular cAMP and IP levels and performed additionally linear regression analyses to determine the basal activity independently from the mutant's cell surface expression in COS-7 and $\mathrm{HEK}_{\mathrm{GT}}$ cells.

Results and Conclusions: Only one (F631I) of the five investigated TSHR variants displayed constitutive activity for $\mathrm{G}_{\alpha} \mathrm{S}$ signaling and showed correlation with the clinical phenotype. The previous false classification of T620I and L677V as CAMs is most likely related to the circumstance that both mutations were characterized in cell lines stably expressing the mutated receptor construct without assessing the respective receptor number per cell. Other molecular etiologies for the nonautoimmune hyperthyroidism and/or hot thyroid carcinomas in these 3 patients and one family should be elucidated.
\end{abstract}




\section{Introduction}

Activating somatic mutations of the TSHR have been found in hot thyroid nodules and hot thyroid carcinomas. Activating TSHR germline mutations occur in familial nonautoimmune hyperthyroidism and sporadic congenital hyperthyroidism ${ }^{1}$. Moreover, inactivating mutations have been reported in cases of resistance to thyrotropin (TSH) ${ }^{2}$. Constitutively activating mutations (CAMs) of the TSHR gene induce a ligand-independent state of activation, which results in a permanent activation of the $\mathrm{G}_{\alpha} \mathrm{s}$-and in some cases also the $\mathrm{G}_{\alpha} \mathrm{q}$-mediated signaling pathway ${ }^{3 ; 4}$.

However, also TSHR variants have been described, which did not affect in vitro TSHR function such as D727E ${ }^{5 ; 6}$ and Pro52Thr ${ }^{7}$. Recently, Gozu et al. ${ }^{8}$ described a TSHR germline mutation (N372T) located in the extracellular domain. It's association with euthyroidism in 13 family members was in line with it's lack of constitutive activity as demonstrated by linear regression analysis of constitutive activity as a function of TSHR expression (LRA). Moreover, Mueller et al. ${ }^{9}$ demonstrated the limitations of the current methods to precisely determine if mutants with only a slight increase of the basal activity are constitutively active or not. This study showed that the characterizations of TSHR mutations regarding their constitutive activity should always include the determination of the LRA and should consider the influence of the in vitro cell and/or vector system on the basal cAMP accumulation. Especially the determination of the constitutive activity of the R310C substitution in $\mathrm{CHO}$ cell lines demonstrated the pitfalls for the in vitro determination of constitutive TSHR activity ${ }^{9 ; 10}$. For most (90\%) TSHR mutations the constitutive activity was determined in vitro using the COS-7 cell system ${ }^{11}$. Moreover, these studies also demonstrated that comprehensive clinical characterization of these patients is an important adjunct to classify the activity of these mutations.

The updating of the TSHR mutation database (http://innere.uniklinikum-leipzig.de/tsh) led to the identification of three in vivo TSHR variants with no functional in vitro characterization. Variant F631I has been identified in a patient with toxic metastasizing follicular carcinoma associated with a second TSHR mutation D633Y, which has previously been characterized in 
COS-7 cells as constitutively active ${ }^{12 ; 13}$. TSHR mutation F666 has been found in a hot nodule of a patient with toxic multinodular goiter and I691F was identified in a family with nonautoimmune hyperthyroidism and was only shown to segregate with the phenotype of nonautoimmune hyperthyroidism. ${ }^{14 ; 15}$. Furthermore, T620I and L677V have been identified in patients with a hot follicular carcinoma (T620I) and a hot Hürthle cell thyroid carcinoma (L677V) and were previously characterized in $\mathrm{CHO}$ and in 3T3-Vill cell lines, respectively, stably expressing the mutant without determination of TSHR cell surface expression ${ }^{16 ; 17}$. Therefore, F63I, F666L and I691F were functionally characterized by determination of cell surface expression, basal and TSH-mediated cAMP production, basal and TSH-mediated IP accumulation and LRAs to evaluate their role in nonautoimmune hyperthyroidism and hot thyroid carcinomas. Furthermore, we re-examined the previously published constitutively activating mutations $\mathrm{T} 620 \mathrm{I}$ and $\mathrm{L} 677 \mathrm{~V}$ in the COS-7 and $\mathrm{HEK}_{\mathrm{GT}}$ cell system, respectively. Only F631I displayed constitutive activity for the cAMP pathway and seems to correlate with the clinical phenotype. The other four investigated mutations showed no constitutive activity for $G_{\alpha} s$ or $G_{\alpha} q$ in COS-7 cells, which was confirmed by LRA. Based on the lack of constitutive activity for T620I, L666F, L677V and I691F in COS-7 and $\mathrm{HEK}_{\mathrm{GT}}$ cells other molecular etiologies for nonautoimmune hyperthyroidism or the hot thyroid carcinomas in these patients should be elucidated. 


\section{Material and Methods}

Site-directed mutagenesis - TSHR mutants were constructed as previously described ${ }^{18}$.

Cell culture and transient expression of mutant TSHRs - COS-7 cells were grown in high glucose Dulbecco's modified Eagle's medium (DMEM; PAA Laboratories, Pasching, Austria) supplemented with $10 \%$ FCS, $100 \mathrm{U} / \mathrm{ml}$ penicillin and $100 \mu \mathrm{g} / \mathrm{ml}$ streptomycin (Gibco Life technologies, Paisley, UK) at $37{ }^{\circ} \mathrm{C}$ in a humidified $5 \% \mathrm{CO}_{2}$ incubator. Grip Tite ${ }^{\mathrm{TM}} 293 \mathrm{MSR}$ cells $\left(\mathrm{HEK}_{\mathrm{GT}}\right.$ cells; Invitrogen Group, Paisley, UK) were grown in high glucose Dulbecco's modified Eagle's medium (DMEM) supplemented with $10 \%$ FCS, $1 \%$ nonessential amino acids (PAA Laboratories, Pasching, Austria), $100 \mathrm{U} / \mathrm{ml}$ penicillin, $100 \mu \mathrm{g}$ streptomycin and $1 \%$ geneticin (Gibco Life technologies, Paisley, UK) at $37{ }^{\circ} \mathrm{C}$ in a humidified $5 \% \mathrm{CO}_{2}$ incubator. Cells were transiently transfected in 12 -well plates $\left(1 \times 10^{5}\right.$ cells per well for COS7 and $1.4 \times 10^{5}$ cells per well using HEK $\left._{\mathrm{GT}}\right)$ or 24 -well plates $\left(0.5 \times 10^{5}\right.$ cells per well for COS-7 and $0.7 \times 10^{5}$ cells per well using $\left.\mathrm{HEK}_{\mathrm{GT}}\right)$ with $1 \mu \mathrm{g}$ and $0.5 \mu \mathrm{g}$ DNA per well, respectively, using the GeneJammer ${ }^{\circledR}$ Transfection Reagent (Stratagene, Amsterdam, NL).

FACS analyses - The TSH receptor cell surface expression level was quantified as described by Mueller et al. ${ }^{9}$.

cAMP accumulation assay - Determination of intracellular cAMP levels were performed as described by Mueller et al. ${ }^{9}$.

Linear regression analysis of constitutive activity as a function of TSHR expression (slopes) The constitutive activity is expressed as basal cAMP formation as a function of receptor expression determined by FACS. COS-7 and $\mathrm{HEK}_{\mathrm{GT}}$ cells were transiently transfected in 24well plates with increasing concentrations of wt or mutant TSHR plasmid DNA $(50 ; 100 ; 200$; 300; 400 and $500 \mathrm{ng}$ per well). To transfect a constant DNA amount of $500 \mathrm{ng}$ empty vector plasmid DNA was added to the mutant or wt DNA. For determination of cell surface 
expression see "FACS analyses". Basal cAMP formation as a function of receptor expression was analyzed using the linear regression module of GraphPad Prism 4 for Windows.

Activation of inositolphosphate formation - Determination of inositolphosphate formation were performed as described by Jaeschke et al. ${ }^{19}$.

Statistics - Statistical analysis was carried out using the Mann-Whitney nonparametric $t$ test using GraphPad Prism 4 for Windows.

\section{Results}

To evaluate the impact of the TSHR mutations with the patients clinical phenotype all mutations were functionally tested regarding cell surface expression, basal and TSH-mediated intracellular cAMP accumulation and basal and TSH-mediated production of inositolphosphates (IP). Furthermore, we performed linear regression analyses (LRA) to examine the basal activity independently from the mutant's cell surface expression. Several methods to measure the basal TSHR $\mathrm{G}_{\alpha} \mathrm{s}$ activity in vitro, e.g. direct measurement of the cAMP concentration, a luciferase assay using the cAMP response element (CRE) and measurement of the adenylate cyclase activity have been used in recent studies ${ }^{20}$. Currently the best method to measure ligand independent activation of the TSHR by mutations is the slope method. This approach allows experimentally the determination of the basal activity independently from the receptors cell surface expression ${ }^{9 ; 20}$.

The cell surface expression of the four investigated TSHR constructs was between $40-103 \%$ (wt TSHR $=100 \%)$ in COS-7 cells (Table 1$)$ and in HEK $_{\mathrm{GT}}$ cells the TSHR mutations were expressed similarly (Table 2). Mutations T620I and F666L showed nearly the same expression as the wt TSHR. I691F was expressed to $88 \%$ in COS-7 cells and to $94 \%$ in HEK $_{\mathrm{GT}}$ cells. The lowest cell surface expression levels were determined for mutation L677V and F631I (Table 1 and 2). 
Interestingly, in both characterized cell lines four of the five characterized mutations showed no increase in basal cAMP production. The relative fold increases were even slightly below the basal activity measured for the wt TSHR $($ set $=1)$. This accounts for mutations T620I (COS-7: 0.7; HEK $\mathrm{GT}_{\mathrm{GT}}$ 0.6), F666L (COS-7: 0.6; HEK $\mathrm{GT}_{\mathrm{GT}}$ 0.8) and I691F (COS-7: 0.8; HEK $\mathrm{GT}_{\mathrm{GT}}$ : 0.9). The basal cAMP production for L677V was the same as determined for the wt TSHR in COS-7 and was confirmed by the same basal activity in HEK $_{\mathrm{GT}}$ cells (Table 1 and 2). Only variant F631I revealed constitutive activity in terms of an elevated basal cAMP level with a relative fold change to 3.7 (COS-7) and $4.8\left(\mathrm{HEK}_{\mathrm{GT}}\right)$ compared with the wt TSHR. TSHmediated signaling of T620I and F666L was unaltered whereas F631I, L677V and I691F revealed a slight but significant decrease in cAMP production (Table 1). However, after TSH administration in $\mathrm{HEK}_{\mathrm{GT}}$ cells no significant changes in cAMP production were measured for all investigated constructs when compared with the wt TSHR. (Table 2). The experimental verification of the receptors constitutive activity by LRA in both cell systemy confirmed the observation that mutations T620I, F666L, L677V and I691F were not constitutively active. The slopes of the LRA experiment ranged from 0.4 to 1.4 in COS-7 cells (wt TSHR $=1$ ) and were in between 0.4 and 1.8 in $\mathrm{HEK}_{\mathrm{GT}}$ cells. In contrast, F631I was confirmed to be a constitutively active mutant by LRA with a slope of 8.6 and 19.0, respectively (Table 1 and 2).

The basal IP levels of the five receptor constructs showed no discrepancies in comparison with the wt TSHR. A reduction of intracellular IP production after TSH stimulation was observed for F631I, T620I, F666L and L677V, whereas I691F IP accumulation after TSH administration was comparable with the wt TSHR. (Table 1 and 2). 


\section{Discussion}

In this study we functionally characterized three TSHR variants (F631I, F666L and I691F) previously reported in patients with hyperthyroidism and or hot thyroid carcinomas for the first time. These TSHR variants were previously identified in patients with toxic metastasizing follicular carcinoma and with a toxic multinodular goiter, respectively, and in a family with nonautoimmune hyperthyroidism ${ }^{12 ; 14 ; 15}$. With an LRA of 8.6 the mutation F631I is clearly constitutively active (Table 1, Figure 1). However, F666L and I691F did not display constitutive activity in terms of increased basal activity for the $G_{\alpha} s$ - and the $G_{\alpha} q$-pathway. Moreover, F666L is not able to activate $\mathrm{G}_{\alpha} \mathrm{q}$ after TSH administration, whereas I691F displayed a similar phenotype like the wt after TSH stimulation for $\mathrm{G}_{\alpha} \mathrm{q}$. These findings support the conclusion that $\mathrm{F} 666 \mathrm{~L}$ and $\mathrm{I} 691 \mathrm{~F}$ are not constitutively activating. The constitutively activating mutation F631I has been identified in a patient with thyroid follicular cancer and was associated with two toxic thyroid nodules. In this patient each nodule contained a different TSHR mutation namely D633Y and F631I ${ }^{12}$. Further genetic alterations e.g. of the RAS gene or PAX8-PPARy rearrangements, which might contribute to the phenotype of follicular carcinoma, were excluded in this patient. Variant D633Y was previously identified by Porcellini and co workers in a patient with nonautoimmune hyperthyroidism ${ }^{21}$ and a comprehensive functional characterization confirmed that this amino acid substitution was the molecular origin of hyperthyroidism ${ }^{13}$. With the functional data of the newly characterized F631I variant we confirmed that the patient with thyroid follicular cancer harbored two different CAMs.

The in vitro functionally neutral variant F666L, which was previously identified in a hot nodule of a patient with toxic multinodular goiter could be associated with a further constitutively activating somatic TSHR mutation like in the patient reported by Gozu et al. ${ }^{22}$. The previously reported in vitro neutral D727E variant has been identified in 12 of 56 (21.4\%) hot nodules in the nodular tissue and also in DNA extracted from the lymphocytes ${ }^{22}$. In one patient it was found homozygous and accompanied by the constitutively activating TSHR mutation D633Y and in 11 patients the polymorphism was heterozygous. Alternatively 
and more likely it is associated with a further currently unknown molecular cause for the hot nodule, which remains to be identified in about $30-40 \%$ of the hot nodules without somatic TSHR mutations ${ }^{22 ; 23}$.

The in vitro functionally neutral TSHR variant I691F identified in a family with nonautoimmune hyperthyroidism and shown to segregate with the phenotype of nonautoimmune hyperthyroidism is located in the intracellular cytoplasmic part of the TSHR. A further in vitro functionally neutral variant is known in this region, D727E, which shows wt like expression levels and signaling capacities ${ }^{5 ; 6}$. Also for the TSHR related LHCGR and FSHR no mutations leading to an elevated basal cAMP level in the homologous region have been reported. The occurrence of a neutral TSHR germline variant was recently shown in a Turkish family. All 13 family members carried the neutral substitution N372T and were euthyroid. Only one family member showed hyperthyroidism due to a second somatic mutation at position 281 ( $\mathrm{S}$ to $\mathrm{N}$ ), which turned out to be the molecular cause of hyperthyroidism in this single family member. Therefore, the occurrence of a TSHR germline mutation in a family (even if it segregates with hyperthyroidism) is not necessarily an argument for it's constitutive activity.

The variants $\mathrm{T} 620 \mathrm{I}$ and $\mathrm{L} 677 \mathrm{~V}$ detected as somatic mutations in a hot follicular carcinoma (T620I) and in a hot Hürthle cell thyroid carcinoma (L677V) and previously characterized in CHO and in 3T3-Vill cell lines, respectively, are also not constitutively activating for the $\mathrm{G}_{\alpha} \mathrm{s}-$ mediated pathway. F666L even showed a reduction for the TSH-mediated $\mathrm{G}_{\alpha} \mathrm{q}$ activation. The previous false classification of T620I and L677V as CAMs is most likely related to the circumstance that both mutations were characterized in cell lines stably expressing the mutated receptor construct without assessing the respective receptor numbers per cell ${ }^{16 ; 17}$. The basal activity of GPCRs tightly correlates with the number of receptors expressed on the cell surface. It is unlikely that the receptor numbers of the cell line harboring the wt TSHR was the same as the cell line expressing the mutation. A comparison of the receptors basal activity in relation to the wild type is impossible without the determination of the receptor cell surface expression. Therefore, the best experimental approach to characterize the basal 
activity independently from the receptors cell surface expression is the determination of the LRA ${ }^{9}$. The resulting slopes are to date the best parameter to determine if a receptor is constitutively active. This was previously shown for the TSHR mutation R310C, which was also initially characterized in CHO cells stably expressing the mutated receptor construct ${ }^{10}$. However, LRA studies of this particular TSHR mutation after transient expression in COS-7 and $\mathrm{HEK}_{\mathrm{GT}}$ cells revealed no constitutive activity ${ }^{9}$.

In the patient with a follicular thyroid carcinoma besides the in vitro functionally neutral T620I TSHR variant another point mutation in the Ki-RAS gene (G12C) was identified ${ }^{16}$. In follicular thyroid carcinomas $R A S$ mutations occur in $40-50 \%$ and are considered to represent an early step in tumor formation ${ }^{24}$. Moreover, PAX8/PPAR $\gamma$ rearrangements can be identified in follicular carcinomas. This was not investigated in this case report. No further candidate genes were screened in the hot Hürthle cell carcinoma with the vitro functionally neutral L677V TSHR variant ${ }^{17}$. Therefore, the molecular cause for the hot thyroid carcinoma in this patient remains unknown.

Up to date, ten activating TSHR mutations have been reported in nine differentiated hot thyroid carcinomas (Table 3). Among these five follicular carcinomas with six different activating TSHR gene mutations: I486F ${ }^{25}$, T620I ${ }^{16}$, F631I and D633Y ${ }^{12}$, T632A and T632I ${ }^{26}$ were reported. In addition, a D633H mutation was identified in a hot insular thyroid carcinoma $^{27}$, a M453T mutation was detected in a 11-year-old girl with a hyperfunctioning thyroid papillary carcinoma ${ }^{28}$, a L512R mutation was found in an autonomously functioning papillary carcinoma ${ }^{29}$ and L677V was identified in a hot Hürthle cell carcinoma ${ }^{17}$. Except for the vitro functionally neutral T620I and V677L variants, which were previously characterized in cell lines stably expressing the receptor construct the other TSHR mutations found in hot thyroid carcinomas were done by transient expression in COS-7 cells with the results summarized in Table 2. Therefore, only the hot thyroid carcinomas with the TSHR mutations M453T, I486F, L512R, F631I, T632A, T632I, D633H and D633Y are associated with constitutively activating TSHR mutations. 


\section{Acknowledgements}

We would like to thank Saskia Fiedler and Anja Moll for their excellent technical assistance.

This work was supported by grants of the Deutsche Forschungsgemeinschaft (DFG) (JA1927/1-1, Pa 423/15-2 and 14-1). The authors have nothing to declare. 
Reference List

(1) Gozu, H.I., Lublinghoff, J., Bircan, R., Paschke, R. (2010) Genetics and phenomics of inherited and sporadic non-autoimmune hyperthyroidism. Mol Cell Endocrinol.

(2) Kopp, P. (2001) The TSH receptor and its role in thyroid disease. Cell Mol Life Sci 58, (9),pp. 1301-1322.

(3) Duprez, L., Parma, J., Van Sande, J., Rodien, P., Dumont, J.E., Vassart, G., et al. (1998) TSH Receptor Mutations and Thyroid Disease. Trends Endocrinol Metab 9, (4),pp. 133-140.

(4) Parma, J., Duprez, L., VanSande, J., Paschke, R., Tonacchera, M., Dumont, J., et al. (1994) Constitutively Active Receptors As A Disease-Causing Mechanism. Molecular and Cellular Endocrinology 100, (1-2),pp. 159-162.

(5) Nogueira, C.R., Kopp, P., Arseven, O.K., Santos, C.L., Jameson, J.L., MedeirosNeto, G. (1999) Thyrotropin receptor mutations in hyperfunctioning thyroid adenomas from Brazil. Thyroid 9, (11),pp. 1063-1068.

(6) Sykiotis, G.P., Neumann, S., Georgopoulos, N.A., Sgourou, A., Papachatzopoulou, A., Markou, K.B., et al. (2003) Functional significance of the thyrotropin receptor germline polymorphism D727E. Biochemical and Biophysical Research Communications 301, (4),pp. 1051-1056.

(7) Sunthornthepvarakul, T., Hayashi, Y., Refetoff, S. (1994) Polymorphism of a variant human thyrotropin receptor (hTSHR) gene. Thyroid 4, (2),pp. 147-149.

(8) Gozu, H.I., Mueller, S., Bircan, R., Krohn, K., Ekinci, G., Yavuzer, D., et al. (2008) A New Silent Germline Mutation of the TSH Receptor: Coexpression in a Hyperthyroid Family Member with a Second Activating Somatic Mutation. Thyroid 18, (5),pp. 499-508.

(9) Mueller, S., Gozu, H.I., Bircan, R., Jaeschke, H., Eszlinger, M., Lueblinghoff, J., et al. (2009) Cases of borderline in vitro constitutive thyrotropin receptor activity: how to decide whether a thyrotropin receptor mutation is constitutively active or not? Thyroid 19, (7),pp. 765-773.

(10) Russo, D., Betterle, C., Arturi, F., Chiefari, E., Girelli, M.E., Filetti, S. (2000) A novel mutation in the thyrotropin (TSH) receptor gene causing loss of TSH binding but constitutive receptor activation in a family with resistance to TSH. J Clin Endocrinol Metab 85, (11),pp. 4238-4242.

(11) Kleinau, G., Brehm, M., Wiedemann, U., Labudde, D., Leser, U., Krause, G. (2007) Implications for molecular mechanisms of glycoprotein hormone receptors using a new sequence-structure-function analysis resource. Molecular Endocrinology 21, (2),pp. 574-580.

(12) Fuhrer, D., Tannapfel, A., Sabri, O., Lamesch, P., Paschke, R. (2003) Two somatic TSH receptor mutations in a patient with toxic metastasising follicular thyroid carcinoma and non-functional lung metastases. Endocrine-Related Cancer 10, (4),pp. 591-600. 
(13) Kosugi, S., Shenker, A., Mori, T. (1994) Constitutive activation of cyclic AMP but not phosphatidylinositol signaling caused by four mutations in the 6th transmembrane helix of the human thyrotropin receptor. FEBS Lett 356, (2-3),pp. 291-294.

(14) Liu, Z., Sun, Y., Dong, Q., He, M., Cheng, C.H., Fan, F. (2008) A novel TSHR gene mutation (Ile691Phe) in a Chinese family causing autosomal dominant nonautoimmune hyperthyroidism. J Hum Genet 53, (5),pp. 475-478.

(15) Tassi, V., Di Cerbo, A., Porcellini, A., Papini, E., Cisternino, C., Crescenzi, A., et al. (1999) Screening of thyrotropin receptor mutations by fine-needle aspiration biopsy in autonomous functioning thyroid nodules in multinodular goiters. Thyroid 9, (4),pp. 353-357.

(16) Niepomniszcze, H., Suarez, H., Pitoia, F., Pignatta, A., Danilowicz, K., Manavela, M., et al. (2006) Follicular carcinoma presenting as autonomous functioning thyroid nodule and containing an activating mutation of the TSH receptor (T620I) and a mutation of the Ki-RAS (G12C) genes. Thyroid 16, (5),pp. 497-503.

(17) Russo, D., Wong, M.G., Costante, G., Chiefari, E., Treseler, P.A., Arturi, F., et al. (1999) A Val 677 activating mutation of the thyrotropin receptor in a Hurthle cell thyroid carcinoma associated with thyrotoxicosis. Thyroid 9, (1),pp. 13-17.

(18) Jaschke, H., Neumann, S., Moore, S., Thomas, C.J., Colson, A.O., Costanzi, S., et al. (2006) A low molecular weight agonist signals by binding to the transmembrane domain of thyroid-stimulating hormone receptor (TSHR) and luteinizing hormone/chorionic gonadotropin receptor (LHCGR). Journal of Biological Chemistry 281, (15),pp. 9841-9844.

(19) Jaeschke, H., Kleinau, G., Sontheimer, J., Mueller, S., Krause, G., Paschke, R. (2008) Preferences of transmembrane helices for cooperative amplification of G(alpha)s and G (alpha)q signaling of the thyrotropin receptor. Cell Mol Life Sci 65, (24),pp. 40284038 .

(20) Mueller, S., Jaeschke, H., Paschke, R. (2010) Current Standards, Variations and Pitfalls for the Determination of Constitutive TSHR Activity in vitro. Methods in Enzymology. In press.

(21) Porcellini, A., Ciullo, I., Laviola, L., Amabile, G., Fenzi, G., Avvedimento, V.E. (1994) Novel mutations of thyrotropin receptor gene in thyroid hyperfunctioning adenomas. Rapid identification by fine needle aspiration biopsy. J Clin Endocrinol Metab 79, (2),pp. 657-661.

(22) Gozu, H.I., Bircan, R., Krohn, K., Muller, S., Vural, S., Gezen, C., et al. (2006) Similar prevalence of somatic TSH receptor and Gs alpha mutations in toxic thyroid nodules in geographical regions with different iodine supply in Turkey. European Journal of Endocrinology 155, (4),pp. 535-545.

(23) Trulzsch, B., Krohn, K., Wonerow, P., Chey, S., Holzapfel, H.P., Ackermann, F., et al. (2001) Detection of thyroid-stimulating hormone receptor and G(s)alpha mutations: in 75 toxic thyroid nodules by denaturing gradient gel electrophoresis. Journal of Molecular Medicine-Jmm 78, (12),pp. 684-691.

(24) Nikiforova, M.N., Nikiforov, Y.E. (2009) Molecular diagnostics and predictors in thyroid cancer. Thyroid 19, (12),pp. 1351-1361. 
(25) Camacho, P., Gordon, D., Chiefari, E., Yong, S., DeJong, S., Pitale, S., et al. (2000) A Phe 486 thyrotropin receptor mutation in an autonomously functioning follicular carcinoma that was causing hyperthyroidism. Thyroid 10, (11),pp. 1009-1012.

(26) Spambalg, D., Sharifi, N., Elisei, R., Gross, J.L., Medeiros-Neto, G., Fagin, J.A. (1996) Structural studies of the thyrotropin receptor and Gs alpha in human thyroid cancers: low prevalence of mutations predicts infrequent involvement in malignant transformation. J Clin Endocrinol Metab 81, (11),pp. 3898-3901.

(27) Russo, D., Tumino, S., Arturi, F., Vigneri, P., Grasso, G., Pontecorvi, A., et al. (1997) Detection of an activating mutation of the thyrotropin receptor in a case of an autonomously hyperfunctioning thyroid insular carcinoma. J Clin Endocrinol Metab 82, (3),pp. 735-738.

(28) Mircescu, H., Parma, J., Huot, C., Deal, C., Oligny, L.L., Vassart, G., et al. (2000) Hyperfunctioning malignant thyroid nodule in an 11-year-old girl: pathologic and molecular studies. J Pediatr 137, (4),pp. 585-587.

(29) Gozu, H., Avsar, M., Bircan, R., Sahin, S., Ahiskanali, R., Gulluoglu, B., et al. (2004) Does a Leu 512 Arg thyrotropin receptor mutation cause an autonomously functioning papillary carcinoma? Thyroid 14, (11),pp. 975-980.

(30) Cetani, F., Tonacchera, M., Vassart, G. (1996) Differential effects of $\mathrm{NaCl}$ concentration on the constitutive activity of the thyrotropin and the luteinizing hormone chorionic gonadotropin receptors. Febs Letters 378, (1),pp. 27-31.

(32) de Roux N, Polak M, Couet J, Leger J, Czernichow P, Milgrom E, Misrahi M. et al. (1996) A neomutation of the thyroid-stimulating hormone receptor in a severe neonatal hyperthyroidism. J Clin Endocrinol Metab 81, (6),pp. 2023-2026.

(33) Claeysen S., Govaerts C., Lefort A., Van Sande J., Costagliola S., Pardo L., et al. (2002) A conserved Asn in TM7 of the thyrotropin receptor is a common requirement for activation by both mutations and its natural agonist FEBS Letters 517, (1-3),pp. 195-200

(34) Parma J, Van Sande J, Swillens S, Tonacchera M, Dumont J., Vassart G. (1995) Somatic mutations causing constitutive activity of the thyrotropin receptor are the major cause of hyperfunctioning thyroid adenomas: identification of additional mutations activating both the cyclic adenosine 3',5'-monophosphate and inositol phosphate-Ca2+ cascades. Molecular Endocrinology 9, (6),pp. 725-33

(35) Neumann S., Claus M., Paschke R.. (2005) Interactions between the extracellular domain and the extracellular loops as well as the 6th transmembrane domain are necessary for TSH receptor activation. European Journal of Endocrinology 152, (4),pp. 625-34

(36) Ho S.C., Goh S.S., Su Q., Khoo D.H. (2005) Cysteine 390 mutation of the TSH receptor modulates its ectodomain as an inverse agonist on the serpentine domain with decrease in basal constitutive activity. Molecular and Cellular Endocrinology 245, (1-2),pp. 158-68

(37) Kosugi S, Hai N, Okamoto H, Sugawa H, Mori T. (2000) A novel activating mutation in the thyrotropin receptor gene in an autonomously functioning thyroid nodule 
1

2

3

4

5

6

7

8

9

10

11

12

13

14

15

16

17

18

19

20

21

22

23

24

25

26

27

28

29

30

31

32

33

34

35

36

37

38

39

40

41

42

43

44

45

46

47

48

49

50

51

52

53

54

55

56

57

58

59

60

developed by a Japanese patient. European Journal of Endocrinology 143, (4),pp. 471-4777

(38) Urizar E., Claeysen S., Deupí X., Govaerts C., Costagliola S., Vassart G., et al. (2005) An activation switch in the rhodopsin family of $\mathrm{G}$ protein-coupled receptors: the thyrotropin receptor. Journal of Biological Chemistry 280, (17),pp. 17135-41

(39) Paschke R., Tonacchera M., Van Sande J., Parma J., Vassart G. (1994) Identification and functional characterization of two new somatic mutations causing constitutive activation of the thyrotropin receptor in hyperfunctioning autonomous adenomas of the thyroid. J Clin Endocrinol Metab 79, (6),pp. 1785-9

(40) Neumann S., Krause G., Chey S., Paschke R. (2001) A free carboxylate oxygen in the side chain of position 674 in transmembrane domain 7 is necessary for TSH receptor activation. Molecular Endocrinology 15, (8),pp 1294-305 
Table 1. Functional characterization of the TSHR constructs in COS-7 cells

\begin{tabular}{|c|c|c|c|c|c|c|c|}
\hline \multirow{2}{*}{ Construct } & \multirow{2}{*}{ Localization } & \multirow{2}{*}{$\begin{array}{l}\text { Cell surface } \\
\text { expression }\end{array}$} & \multicolumn{3}{|c|}{ cAMP accumulation } & \multicolumn{2}{|c|}{ IP accumulation $\mid P s(\%[\mid P S+P I])$} \\
\hline & & & basal & $100 \mathrm{mU} / \mathrm{ml} \mathrm{TSH}$ & LRA (slope) & basal & $100 \mathrm{mU} / \mathrm{ml} \mathrm{TSH}$ \\
\hline wt TSHR & & 100 & 1 & $15.6 \pm 0.5$ & 1 & $3.8 \pm 0.4$ & $30.8 \pm 6.2$ \\
\hline pcDNA & & $3 \pm 1$ & $0.2 \pm 0.1$ & $0.3 \pm 0.1$ & - & $4.1 \pm 0.9$ & $4.2 \pm 1.1$ \\
\hline T6201 & TMH6 & $103 \pm 2$ & $0.7 \pm 0.3$ & $17.1 \pm 0.9$ & $0.4 \pm 0.1$ & $4.0 \pm 0.2$ & $19.4 \pm 0.5$ \\
\hline F631I & TMH6 & $40 \pm 2^{*}$ & $3.7 \pm 0.5^{\text {** }}$ & $12.0 \pm 0.9^{\star \star}$ & $8.6 \pm 0.7^{\star}$ & $4.2 \pm 0.4$ & $6.4 \pm 0.4$ \\
\hline F666L & TMH7 & $98 \pm 9$ & $0.6 \pm 0.1$ & $14.7 \pm 3.7$ & $0.8 \pm 0.1$ & $2.9 \pm 0.7$ & $9.2 \pm 1.3$ \\
\hline L677V & TMH7 & $66 \pm 5^{\star}$ & $1.0 \pm 0.2$ & $12.1 \pm 1.1^{\star \star}$ & $1.4 \pm 0.6$ & $3.7 \pm 0.4$ & $7.6 \pm 1.3$ \\
\hline $1691 \mathrm{~F}$ & C-term. & $88 \pm 6$ & $0.8 \pm 0.1$ & $11.2 \pm 0.6^{\star \star}$ & $0.7 \pm 0.1$ & $4.2 \pm 0.4$ & $28.7 \pm 0.8$ \\
\hline
\end{tabular}

COS-7 cells were transfected with wt TSHR or various mutant TSHRs. The vector pcDNA3.1(-)/hygromycin was used as a control. The TSHR is characterized by an elevated cAMP level compared to the control vector alone ${ }^{30}$. Therefore, cAMP accumulation is expressed relative to wt TSHR basal level. TSH-mediated levels of cAMP and IP accumulation were determined after treatment of cells with $100 \mathrm{mU} / \mathrm{ml} \mathrm{TSH}$. Expression of wt and mutant TSHRs were quantified on a FACS flow cytometer. Data are given as mean \pm standard deviation $(\mathrm{SD})$ of at least two independent experiments $(\mathrm{n}=2)$, each carried out in duplicate. Constitutive activity by linear regression analyses was determined for $\mathrm{G}_{\alpha} \mathrm{s}$ - and not for $\mathrm{G}_{\alpha} \mathrm{q}$-signaling due to the fact that the wt TSHR do not show elevated $\mathrm{G}_{\alpha} \mathrm{q}$-levels. $(\mathrm{TMH}=$ transmembrane helix; C-term. $=\mathrm{C}$-terminus $) ; * * \mathrm{p}<0.001, * * \mathrm{p}=0.001-0.01,{ }^{*} \mathrm{p}=0.01-0.05$ 
Table 2. Functional characterization of the TSHR constructs in $\mathrm{HEK}_{\mathrm{GT}}$ cells

\begin{tabular}{|c|c|c|c|c|c|c|c|}
\hline \multirow{2}{*}{ Construct } & \multirow{2}{*}{ Localization } & \multirow{2}{*}{$\begin{array}{l}\text { Cell surface } \\
\text { expression }\end{array}$} & \multicolumn{3}{|c|}{ cAMP accumulation } & \multicolumn{2}{|c|}{ IP accumulation $I P_{S}\left(\%\left[I P_{s}+P I\right]\right)$} \\
\hline & & & basal & $100 \mathrm{mU} / \mathrm{ml} \mathrm{TSH}$ & LRA (slope) & basal & $100 \mathrm{mU} / \mathrm{ml} \mathrm{TSH}$ \\
\hline wt TSHR & - & 100 & 1 & $40.0 \pm 1.9$ & 1 & $0.6 \pm 0.1$ & $10.7 \pm 1.8$ \\
\hline pcDNA & - & $1 \pm 0$ & $0.3 \pm 0.1$ & $0.3 \pm 0.1$ & - & $0.4 \pm 0.0$ & $0.6 \pm 0.1$ \\
\hline T6201 & TMH6 & $97 \pm 5$ & $0.6 \pm 0.3$ & $45.1 \pm 5.0$ & $0.4 \pm 0.1$ & $0.6 \pm 0.1$ & $6.0 \pm 0.4^{\star}$ \\
\hline F631I & TMH6 & $46 \pm 3^{\star \star}$ & $4.8 \pm 0.5^{\star}$ & $37.5 \pm 3.8$ & $19.0 \pm 4.0^{\star \star}$ & $0.6 \pm 0.1$ & $1.1 \pm 0.0^{\star}$ \\
\hline F666L & $\mathrm{TMH} 7$ & $106 \pm 8$ & $0.8 \pm 0.1$ & $41.2 \pm 4.1$ & $0.8 \pm 0.2$ & $0.5 \pm 0.0$ & $5.5 \pm 0.6^{\star}$ \\
\hline L677V & $\mathrm{TMH} 7$ & $77 \pm 4^{\star \star}$ & $1.0 \pm 0.2$ & $39.4 \pm 7.0$ & $1.8 \pm 0.3$ & $0.6 \pm 0.0$ & $2.7 \pm 0.3^{\star}$ \\
\hline $1691 \mathrm{~F}$ & C-term. & $94 \pm 2$ & $0.9 \pm 0.1$ & $45.9 \pm 3.9$ & $1.6 \pm 0.2$ & $0.6 \pm 0.0$ & $11.8 \pm 0.8$ \\
\hline
\end{tabular}

HEK $_{\text {GT }}$ cells were transfected with wt TSHR or various mutant TSHRs. The vector pcDNA3.1(-)/hygromycin was used as a control. The TSHR is characterized by an elevated cAMP level compared to the control vector alone ${ }^{30}$. Therefore, cAMP accumulation is expressed relative to wt TSHR basal level. TSH-mediated levels of cAMP and IP accumulation were determined after treatment of cells with $100 \mathrm{mU} / \mathrm{ml} \mathrm{TSH}$. Expression of wt and mutant TSHRs were quantified on a FACS flow cytometer. Data are given as mean \pm standard deviation $(\mathrm{SD})$ of at least two independent experiments $(\mathrm{n}=3)$, each carried out in duplicate. Constitutive activity by linear regression analyses was determined for $\mathrm{G}_{\alpha} \mathrm{s}$ - and not for $\mathrm{G}_{\alpha} \mathrm{q}$-signaling due to the fact that the wt TSHR do not show elevated $\mathrm{G}_{\alpha} \mathrm{q}$-levels. $(\mathrm{TMH}=$ transmembrane helix; C-term. $=$ C-terminus) $;{ }^{* * *} \mathrm{p}<0.001,{ }^{*} \mathrm{p}=0.001-0.01,{ }^{*} \mathrm{p}=0.01-0.05$ 
Table 3. All patients reported up to date with a differentiated hot thyroid carcinoma and a constitutively activating TSHR mutation.

\begin{tabular}{|c|c|c|c|c|c|c|}
\hline \multirow{2}{*}{ Construct } & \multirow{2}{*}{ Reference } & \multirow{2}{*}{ Cell system } & \multirow{2}{*}{$\begin{array}{l}\text { Cell surface } \\
\text { expression }\end{array}$} & \multicolumn{3}{|c|}{ cAMP accumulation } \\
\hline & & & & basal & $100 \mathrm{mU} / \mathrm{ml} \mathrm{TSH}$ & LRA (slope) \\
\hline wt TSHR & - & & $100 \%$ & $100 \%$ & $100 \%$ & 1 \\
\hline \multirow[t]{3}{*}{ M453T } & 29 & - & - & - & - & - \\
\hline & 32 & $\cos -7$ & - & 700 & 80 & - \\
\hline & 19 & $\cos -7$ & 66 & 570 & 84 & 5.2 \\
\hline \multirow[t]{5}{*}{ I486F } & 26 & - & - & - & - & - \\
\hline & 33 & cos-7 & 20 & 400 & - & - \\
\hline & 34 & cos-7 & 17 & 550 & - & - \\
\hline & 35 & $\cos -7$ & 35 & 820 & 83 & - \\
\hline & 36 & $\cos -7$ & 15 & 663 & - & - \\
\hline \multirow[t]{2}{*}{ L512R } & 30 & - & - & - & - & - \\
\hline & 37 & $\cos -7$ & 56 & 325 & 49 & - \\
\hline \multirow[t]{2}{*}{ T620I } & \multirow{2}{*}{16} & 3Т3 Vill & - & 500 & 75 & - \\
\hline & & $\cos -7$ & 103 & 70 & 110 & 0.4 \\
\hline \multirow[t]{2}{*}{ F631I } & \multirow[t]{2}{*}{12} & - & - & - & - & - \\
\hline & & cos-7 & 40 & 370 & 77 & 8.6 \\
\hline \multirow[t]{3}{*}{ T632A } & 24 & - & - & - & - & - \\
\hline & 33 & cos-7 & 50 & 330 & - & - \\
\hline & 38 & cos-7 & 40 & 420 & 145 & - \\
\hline \multirow[t]{3}{*}{ T632I } & 24 & - & - & - & - & - \\
\hline & 13 & cos-7 & 36 & 370 & 82 & - \\
\hline & 39 & cos-7 & 90 & 500 & 100 & - \\
\hline \multirow[t]{3}{*}{$\mathrm{D} 633 \mathrm{H}$} & 25 & - & - & - & - & - \\
\hline & 36 & cos-7 & 84 & 620 & 67 & - \\
\hline & 40 & cos-7 & 123 & 725 & - & - \\
\hline \multirow[t]{2}{*}{ D633Y } & 12 & - & - & - & - & - \\
\hline & 13 & cos-7 & 60 & 405 & 88 & - \\
\hline \multirow[t]{2}{*}{ L677V } & \multirow[t]{2}{*}{17} & $\mathrm{CHO}$ & - & 343 & - & - \\
\hline & & COS-7 & 66 & 100 & 78 & 1.4 \\
\hline
\end{tabular}

Values with grey background were newly determined in this study demonstrating no constitutive activity for L677V and T620I. Only the mutations M453T, I486F, L512R, F631I, T632A, T623I, D633H and D633Y are constitutively activating. The data base sequencestructure-function analysis for glycoprotein hormone receptors was used ${ }^{11}$. 